\title{
Beginning teachers' professional support: a mixed methods social network study
}

Cite as follows: Thomas, L., Tuytens, M., Devos, G., Kelchtermans, G., \& Vanderlinde, R. (2019). Beginning teachers' professional support: A mixed methods social network study.

Teaching and Teacher education, 83, 134-147. doi: 10.1016/j.tate.2019.04.008

Disclaimer: Please note that this version may still slightly differ from the final print version. 


\section{Introduction}

Worldwide, early teacher attrition has been a continuing concern within educational policy and research (Craig, 2017). Many studies have found that professional support, available to beginning teachers (BTs) through their interactions with colleagues, is related to their decision to remain in the profession (e.g., Craig, 2017, issue on teacher attrition). To investigate teachers' interactions and the resources available in these interactions, the social network perspective (SNP) has come to the fore. The SNP offers an ideal framework for managing the complexity inherent in studying teachers' interactions, as it focuses on the relationships among individuals as the unit of analysis (Baker-Doyle, 2010; de Lima, 2010). In this innovative perspective, teachers' attitudes and behaviour are assumed to be affected by their web of relationships and the resources available in these relationships (Carrington, Scott, \& Wasserman, 2005; Penuel, Riel, Krause, \& Frank, 2009). Several educational scholars have made use of the SNP and have proven its value by establishing the importance of teacher interactions for leadership (Pitts \& Spillane, 2009), policy implementation (Coburn \& Russell, 2008), and student achievement (Moolenaar, Sleegers, \& Daly, 2012). SNP studies in the context of teacher induction, however, are scarce (Struyve et al., 2016).

The majority of SNP research focuses solely on network structure. In these studies, the pattern of teachers' relationships is analysed to reveal the extent to which interactions, and as such, an exchange of resources such as professional support, can take place (Van Waes et al., 2016). Several studies, in organisational psychological (e.g., Riehl \& Sipple, 1996) and educational literature (e.g., Thomas, 2007), have found that network structure plays an important role in employees' intentions to remain in the profession. Studies focusing on the network content, i.e., on what flows through teachers' interactions (e.g., Coburn, Russell, Kaufman, \& Stein, 2012), and in which the network structure and its content are combined (Crossley, 2010), particularly in BT retention, are limited. 
This study aims to explore BTs' network and how this is related to their job attitudes, as important precursors of teacher retention. First, by using a mixed-method social network research design (Baker-Doyle, 2015), the study aims to provide a more complete understanding of BTs' network by focusing on both its structure and content. The former reflects BTs' access to professional support, while the latter concerns the content of this professional support. Second, the relatedness of BTs' network to their job attitudes is investigated.

\section{Theoretical framework}

\subsection{Job attitudes}

For over two decades, many countries have been confronted with large numbers of teachers leaving the profession in their first years of practice (Ingersoll \& Strong, 2011). The significance of this 'teacher retention crisis' (Hunt et al., 2003) is reflected in its negative consequences, including teacher shortages (Ingersoll, 2001) and declining trends in student performance (Ronfeldt, Loeb, \& Wyckoff, 2013). The pressing character of this crisis has caused the induction period to be one of the most researched career phases in educational literature (Author et al., 2002). Numerous studies have investigated hindering and supporting factors for teacher retention (e.g., Borman \& Dowling, 2008). In this respect, educational scholars (e.g., Carmeli \& Weisberg, 2006) have taken inspiration from organisational psychological literature concerning job attitudes (e.g., Cummings \& Bigelow, 1976; Lachman \& Aranya, 1986). Job attitudes refer to beliefs, feelings, and thoughts employees have about their profession and organisation (George \& Jones, 1999). In the organisational psychological context, three job attitudes, namely job satisfaction (e.g., Smith, Kendall, \& Hulin, 1969), organisational commitment (e.g., Meyer, Allen, \& Smith, 1993), and intrinsic motivation (e.g., Cummings \& Bigelow, 1976) are considered beneficial for employees and their organisation (Struyve et al., 2016). In the educational context, they have been found to be related to teachers' 
choice to remain in or leave the profession (Struyve et al., 2016; Vansteenkiste et al., 2007). Job satisfaction, described as teachers' cognitive and affective reactions to the extent to which their expectations and the actuality of teaching overlap (Carmeli \& Weisberg, 2006; Skaalvik \& Skaalvik, 2011), has been positively related to teacher retention by numerous studies (e.g., Zembylas \& Papanastasiou, 2006). Furthermore, several scholars (e.g., Meyer, Stanley, Herscovitch, \& Topolnytsky, 2002) have found a strong relationship between affective organisational commitment, defined as feeling emotionally attached to, and having positive feelings of identification with an organisation (Meyer \& Allen, 1991; Mowday, Steers, \& Porter, 1979), and teachers' intentions to stay. Finally, intrinsic motivation to teach, referring to teachers teaching because they enjoy it (van den Broeck, Vansteenkiste, de Witte, Lens, \& Andriessen, 2009), is also found to have a positive effect on teachers' intentions to stay in the profession (Vansteenkiste et al., 2007).

\subsection{A SNP on teachers' first years in practice}

Researchers have recognised that professional support from colleagues positively influences teachers' job attitudes, and as such, retains BTs in the profession (e.g., Struyve et al., 2016; Rippon \& Martin, 2006). The present study defines 'professional support' as assisting teachers in professional growth, and in developing the required skills and competencies (Snoeck et al., 2010). Such professional support is available to a BT through collegial interactions (Van Waes et al., 2016), which reflects teachers' social embeddedness (BakerDoyle, 2010). Studying teachers' collegial interactions and social embeddedness, however, is complex and requires a unique approach that exceeds the individual, considering the interdependency inherent in interactions between people (Baker-Doyle, 2010; Meredith, 2017). The SNP is an emerging approach in education that fits these needs, and is guided by three assumptions (Degenne \& Forsé, 1999). First, the SNP assumes that in relationships among 
individuals, resources such as support and knowledge are exchanged (Kilduff \& Tsai, 2003). These resources, which flow through the network and are transferred via interpersonal interaction, are called 'social capital' (Leana \& Van Buren, 1999; Moolenaar, 2012). In school contexts, for example, teachers can make use of their colleagues' knowledge by interacting with them (Borgatti \& Ofem, 2010). Second, individuals are viewed as interdependent, due to their relationships within the social structure (Wasserman \& Faust, 1994). Applied to school contexts, this means that teachers are connected to each other, and that changes in a dyadic relationship can impact the school's larger social structure, and vice versa (Burt, 2000). Third, an individual's network position plays an important role in their access to resources (Borgatti \& Foster, 2003). For example, when the school's social structure causes many teachers to be isolated from others, their access to resources, will be constrained (Moolenaar, 2012).

\subsection{The structure and content of the network}

Using a SNP enables a focus on the patterns of social relationships (i.e., network structure), as well as the content of relationships (i.e., resources) (Edwards, 2010). Applied to the study's context, this means that the SNP facilitates a focus on both BTs' access to professional collegial support, and the content of this support.

\subsubsection{Network structure}

Investigating network structure can reveal the extent to which interactions, and as such, an exchange of resources, such as professional support, can take place (Van Waes et al., 2016). The network structure is investigated by mapping and measuring patterns of relationships, operationalised within structural properties (Edwards, 2010). Several structural properties have been related to an individual's access to resources in the network (Baker-Doyle, 2015), two of which have been extensively researched-and are applicable in the study's context-i.e., 
centrality and cohesion (Wasserman \& Faust, 1994). Centrality refers to one's network position. In case of a central position, the individual has more access to the resources that exist in the network (Borgatti, 2005; Borgatti, Everett, \& Johnson, 2013). Cohesion is the extent to which individuals in a network are interconnected (Burt, 2000). The more cohesive the network, the more individuals are interconnected. In turn, the more individuals are interconnected, the more they have access to the resources that exist in the relationships between individuals in the network (Burt, 2000; Coleman, 1988). Existing studies in organisational psychological and educational literature reveal that social networks and their social capital can shape people's commitment and intentions to leave the profession (Riehl \& Sipple, 1996; Thomas, 2007). Several studies found that the more individuals are socially tied in the network, the more positive their attitudes are about the profession, and the less likely they are to leave (Ibarra \& Andrews, 1993; Struyve et al., 2016; Thomas, 2007).

\subsubsection{Network content}

To capture a more complete network understanding, the content of the network should also be considered (Coburn et al., 2012). In this case, this pertains to the content of professional support BTs receive through their relationships. The exploration of the professional support content in the current study starts from the notion that the shift from teacher education to the profession is challenging (Author et al., 2002), making professional collegial support for BTs indispensable. BTs are assumed to be in charge with the same responsibilities as their experienced colleagues (Tynjälä \& Heikkinen, 2011). When BTs are unsupported, the challenges they face can feel overwhelming (Goddard \& Foster, 2001), and can lead to an early exit (Mansfield et al., 2014). In a review study by Veenman (1984), the most commonly perceived challenges encountered by BTs are identified: classroom discipline and management, motivating pupils, dealing with individual differences in the classroom, assessment of pupils, 
communication with parents, organisation of class work, insufficient or inadequate teaching materials, and dealing with individual students' problems. These issues were considered challenging by almost all BTs of the 83 studies reviewed, and therefore can be acknowledged as topics that need to be addressed through professional collegial support. Although these challenges are based on a study that took place three decades ago, since that time such challenges continue to be relevant (e.g., Epstein, 2013; Goddard \& Foster, 2001; Smit \& Humpert, 2012), and some have even intensified due to the increased complexity of the profession (OECD, 2005) and the growing diversity in pupil populations (Cochran-Smith \& Power, 2013).

The first challenge, classroom management, concerns planning and organising a structured classroom climate (Odell, 1986), in which the teacher has to maintain order and discipline (Kersaint, Lewis, Potter, \& Meisels, 2007). Motivating pupils, as a second challenge, relates to the task of teachers to stimulate pupils to learn (Skaalvik \& Skaalvik, 2007), as well as value learning (Tschannen-Moran \& Woolfolk Hoy, 2001). The third challenge, is dealing with individual differences in the classroom. Teachers are expected to implement differentiated instruction to take the needs of each individual pupil into account (Cameron, 2017; Levy, 2008). Though this issue is challenging for all teachers, BTs particularly encounter difficulties implementing differentiated instruction (Holloway, 2000; Meister \& Melnick, 2003). Assessing pupils is a fourth challenge and refers to the ability to collect reliable and valid information (Veenman, 1984), and use diverse assessment strategies (Tschannen-Moran \& Woolfolk Hoy, 2001). Several scholars emphasise that not only the assessment strategies, but also the implementation of instructional strategies for teaching the subject matter that is subsequently assessed is challenging (Moir \& Stobbe, 1995; Stansbury \& Zimmerman, 2000). The fifth challenge focuses on communication with parents. BTs are expected to communicate with parents about their pupils' development; however, research reveals that student teachers are 
insufficiently prepared to cultivate and sustain valuable parent-teacher relationships (Epstein, 2013; Willemse, Vloeberghs, De Bruïne, \& Van Eynde, 2016). The organisation of class work is a sixth challenge (Meister \& Melnick, 2003); it addresses time management, handling a high work load, and organising short-term (i.e., lesson preparations) and long-term (i.e., year plan) schedules (Fantilli \& McDougall, 2009; Meister \& Melnick, 2003). The seventh challenge is insufficient or inadequate teaching materials. By collecting a variety of teaching resources with the help of colleagues, BTs can better deal with this challenge (Odell, 1986). The final challenge is dealing with problems of individual students. Teachers work with disadvantaged pupils and pupils with behavioural or socio-emotional difficulties. With a lack of classroom experience, support from colleagues here is imperative (Aelterman, Meysman, Troch, Vanlaer, \& Verkens, 2008).

\section{Aim}

Few studies on professional collegial support in teachers' first years in practice have used the SNP (e.g., Baker-Doyle, 2012; Struyve et al., 2016), in which support for the challenges they face is considered as social capital, i.e., as resources that are transferred through interaction with one another (Degenne \& Forsé, 1999; Kilduff \& Tsai, 2003). Moreover, the available SNP literature primarily focuses on either the network structure, or-to a lesser extentthe network content (Baker-Doyle, 2010). The 'structure' and 'content' of the network, however, are like the two sides of the same coin: "an understanding of either requires the other" (Edwards, 2010, p. 25). Therefore, in line with Baker-Doyle (2015), to strive for a comprehensive picture of BTs' network, this study applies a mixed-method social network research design, wherein both the network structure (reflecting BTs' access to professional collegial support, operationalised as cohesion and centrality) and network content (reflecting the content of professional collegial support by means of BTs' perceived challenges) are 
examined. The aim is to explore BTs' network in its structural and content-related aspects, and how these aspects are related to their job attitudes, as important precursors of teacher retention. This aim is addressed via three research questions (RQ) (Figure-1):

RQ1a-How can the network structure of BTs' primary school team, operationalised as cohesion and centrality, be described?

RQ1b-How can BTs' network content, operationalised as the content of the professional support that is available to BTs through their interactions, be described?

RQ2-How are the network structure of BTs' primary school team and BTs' network content related to their job attitudes?

$<<$ Figure-1 $>>$

\section{Method}

In answering these questions, a mixed-method social network research design was used. In a first step, two case studies with maximum variation were selected from a sample of 10 BTs based on their scores on the job attitude scales. Consequently, the study focuses on the BTs with the highest and lowest job attitude scores. In a second step, all members of the primary school teams of the two BTs were asked to fill out a whole-school survey in which they had to indicate whom from the team members they had contact with for work-related issues. The analyses of these surveys enabled an exploration of the network structure of BTs' primary school team, reflecting BTs' access to professional support (RQ1a). In a third step, semistructured interviews with the BTs were conducted. In these interviews, three issues were discussed. First, to explore the network structure further, they were asked about the interconnectedness of and their position in their primary school team (RQ1a). Second, the BTs were asked about the content of the professional support they received from the team members they nominated in the whole-school survey (RQ1b). Third, they were asked about the link 
between their collegial network and job attitudes (RQ2). These steps are visualised in Figure2.

$<<$ Figure-2>>

\subsection{Sample}

This study is part of a larger research project investigating BTs' professional networks in a sample of ten BTs and their primary school teams. In this project, in line with Henry, Bastian, and Fortner (2011), teachers are considered 'beginner' if they have up to (but no more than) five years of teaching experience. A primary school team is defined as all team members who perform a pedagogical and/or coordinative function.

For the present study, the ten BTs were asked to fill out previously validated scales of job satisfaction, affective organisational commitment, and intrinsic motivation to teach. Table 1 provides an overview of the scales, including Cronbach's alpha coefficients calculated in a previous study in which 292 BTs were questioned via an online survey (see Author et al., 2018). For the selection of information-rich and interesting cases (Hartley, 2004), a purposeful sampling strategy (Palinkas et al., 2015) was used based on BTs' answers on these scales. Particularly, the participant's scores on all three job attitudes were ranked from highest to lowest scores (Figure-3). Based on these scores, two cases were selected: the BT with the highest job attitude scores (Nina; job satisfaction=3.75, affective organisational commitment $=4.00$, intrinsic motivation to teach $=4.00$ ), and the BT with the lowest job attitude scores $($ Jasmine; job satisfaction $=2.25$, affective organisational commitment $=2.33$, intrinsic motivation to teach=2.50). These two cases with maximum variation were selected for the aim of identifying similarities and differences in BTs' networks, and as Palinkas et al. (2015) argue, producing new knowledge through the process of constant comparison. As such, as articulated by Hartley (2004) and Yin (1994), the purpose of case studies is not to yield findings 
generalizable to a broader population, but to get a thorough understanding of phenomena, in this case BTs' network and their relatedness to job attitudes.

$<<$ Table-1 $>>\&<<$ Figure-3>>

\subsection{Instruments}

\subsubsection{Whole-school survey}

An online whole-school survey was administered to all members of the primary school teams of both Nina and Jasmine. The response rates for the school teams were both $100 \%$, exceeding the minimum response rate of $80 \%$ in social network analysis (Huisman \& Steglich, 2008). To gain information on the network structure of BTs' primary school team (RQ1a), a name generator question (Borgatti et al., 2013) was asked to every team member, namely: "With whom did you have contact for work-related issues (in the form of, for example, advice) within the last three months?" A bounded sample (Scott, 2013) was used in which all the team members' names were listed alphabetically in a name roster (Borgatti et al., 2013). The participants could signify as many of the team members as they wanted.

\subsubsection{Semi-structured interview}

Nina and Jasmine were interviewed using a semi-structured interview guide (Supplementary file-A). On average, the interviews lasted 115 minutes. Firstly, to acquire more detailed, qualitative information on the network structure of their primary school team, they were asked about the interconnectedness of the team and their position within that team (RQ1a). Secondly, questions concerning their relationships in the network-also termed interpreting questions (Borgatti et al., 2013)-were posed to gather information on the network content (RQ1b). Specifically, they were asked several interpreting questions concerning the interactions 
they had with the team members whom they indicated as work-related contacts in the name generator of the whole-school survey. In this respect, the semi-structured interviews took an ego-network approach (see Crossley et al., 2015 regarding this approach) to social network analysis. We thus explored the work-related interactions between the BT $(e g o)$ and their nominated team members (alters). In discussing these interactions, we focused on the professional support they received from alters in these interactions. Thirdly, the interviews contained questions concerning BTs' job attitudes and the link with their network (RQ2).

\subsection{Data analysis}

\subsubsection{Quantitative analysis}

For RQ1a concerning the network structure of BTs' primary school team, the wholeschool surveys were analysed. Network maps were generated using NetDraw (Borgatti, 2002). Nina and Jasmine's access to professional collegial support was measured by calculating centrality and cohesion in UCINET (Borgatti, Everett, \& Freeman, 2002). For centrality, indegree and out-degree are used (Borgatti et al., 2013). In-degree is the number of team members who have nominated the BT as being a person whom they had contact with for work-related issues. Out-degree is the number of team members that the BT has nominated as people whom she had contact with for work-related issues (Wasserman \& Faust, 1994). These in-degree and out-degree scores were normalised to enable comparisons, and vary between 0 (no incoming ties/outgoing ties) and 1 (incoming ties from/outgoing ties to everyone in the network). For cohesion, the whole-school measures density and degree centralisation were used (Borgatti et al., 2013). Density is the number of existing relationships in the network divided by the total number of possible relationships (Borgatti et al., 2013). Density scores vary between 0 (no relationships among individuals in the network) and 1 (everyone is connected to everyone in the network). The degree centralisation score was also calculated. This measure describes the 
extent to which cohesion is organised around a particular focal individual; the extent to which the network is dominated by a single actor (Moolenaar, Sleegers, \& Daly, 2011; Wasserman \& Faust, 1994). Degree centralisation varies between 1 (all primary school team members have work-related contact with only a single person in the network, while they themselves are not nominated as being a work-related contact at all) and 0 (all primary school team members are nominated as a work-related contact as frequently).

\subsubsection{Qualitative analysis}

For RQ1a, RQ1b and RQ2 concerning the network structure of BTs' primary school team, BTs' network content, and the relationship between the network and BTs' job attitudes respectively, the semi-structured interviews were analysed. The quantitative analysis mentioned above provides an outsider view on the network by mathematically exploring the network structure (Edwards, 2010). Qualitative analysis can complement the numerical data by listening to teachers' stories about their networks and as such explore the insider view on the network (Edwards, 2010). The interviews were recorded (Baarda, de Goede, \& Teunissen, 2005), transcribed, and then processed using NVivo 11, which focuses on thematic analysis (Braun \& Clarke, 2006). Following Miles and Huberman (1994), for structuring and reducing purposes, the qualitative data were organised into thematic summaries. These summaries entailed three categories: (1) the network structure of BTs' primary school team, (2) BTs' network content, and (3) BTs' job attitudes. In the first category, 'centrality' and 'cohesion' were distinguished. For the second category, deductive coding based on the most frequently perceived challenges by BTs (Veenman, 1984), complemented with recent literature on these challenges (e.g., Cameron, 2017; Willemse et al., 2016) was used. First, the challenges were structured in a coding scheme (Supplementary file-B). One adjustment to the original challenges was made: 'assessment strategies' was replaced by 'instructional and assessment strategies' based on 
several studies that emphasise BTs' challenge with teaching methods (e.g., Moir \& Stobbe, 1995; Stansbury \& Zimmerman, 2000). Second, based on the coding scheme, a table reflecting the number of colleagues who offer support to the BT for these challenges was created (Table3). The third category was subdivided into the categories 'job satisfaction,' 'affective organisational commitment' and 'intrinsic motivation to teach.'

Following Miles and Huberman (1994), the data were analysed in two steps. First, a within-case analysis for both teachers was conducted, resulting in individual case reports. Second, these two cases were then subjected to a cross-case analysis, wherein both cases were compared to explore differences and similarities (i.e., constant comparative method; Glaser \& Strauss, 1967).

To ensure reliability, following Boeije, 't Hart, and Hox (2009), every step in the analysis process was examined critically by peer debriefings. The initial coding was discussed with two researchers. Next, the interviews were coded by the first author and a researcher who was unfamiliar with the study, but is an expert in qualitative research and was trained to understand the categories and coding scheme. The inter-coder reliability was $91 \%$, which is in accordance with the standard of $80 \%$ (Saldaña, 2013).

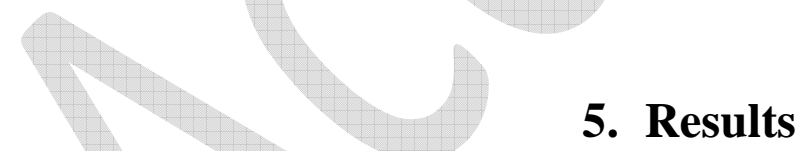

Nina and Jasmine (pseudonyms) both followed a three-year Bachelor programme to become a primary school teacher. After graduation, Nina started working in West Bridge Elementary, and Jasmine was offered a position at Golden Oak (pseudonyms). Nina and Jasmine are similar in terms of ethnicity and age. They both have a full-time position. Moreover, their schools are similar in the percentage of high-risk students, school size (number of pupils), team size (number of primary school team members), educational network, and location (urban/rural). For both teachers, the data collection took place in their second year at their 
respective schools, and their second year of teaching experience. At the time of the interview, Jasmine was on sick leave because of a burn-out. In the interview, she announced that she had decided to quit her job and the teaching profession altogether.

\subsection{RQ1a and RQ1b: the network structure of BTs' primary school team and BTs' network content}

\section{Network structure}

Figure 4 and 5 show the network maps of Nina and Jasmine's primary school team respectively. In both figures, the nodes in the upper network map are sized according to outdegree, while the nodes in the lower network map are sized according to in-degree (with larger nodes having higher out-degree and in-degree scores respectively). The scores for the cohesion and centrality measures are presented in Table-2.

For cohesion, density reveals that $94.4 \%$ of the total number of potential relationships in Nina's school network are actually present. Jasmine's school network has a 72.0\% density, indicating that roughly 3 out of 4 potential relationships are present. These high density scores indicate that both school networks are cohesive, with a slight advantage for Nina's school network. Furthermore, the degree centralisation score of Nina's school is lower than Jasmine's. This means that while in Nina's school the entire team is more interconnected, the cohesion in Jasmine's school is - to some extent- organised around particular nodes.

$$
<<\text { Figure-4>> }
$$

These quantitative findings are corroborated in the interviews. Both teachers indicate that there is a lot of professional exchange between team members. However, while Nina 
emphasises the interconnectedness of everyone in the team, Jasmine states that most, but not all team members, are open to work-related contact.

"Everyone in the team supports everyone professionally.” (Nina)

“There are a lot of professional exchanges between our team members, but not everyone is accessible. Faye was not accessible, for example (...) Eve wasn't really open to professional contact or questions either.” (Jasmine)

Nina argues that the principal plays an important role in contributing to the team's strong interconnectedness. She emphasises his merit for providing an inviting staffroom in which teachers are stimulated to connect to each other. Moreover, Nina mentions that he created an atmosphere which facilitates open communication.

"The principal has an important influence on how the team members interact with each other. He is a real member of the team and if he feels that there are disputes, if he feels the atmosphere is tense, he talks to people about it. He makes sure there is open communication, he senses what's going on and that benefits the team."

Jasmine does not mention the principal in this respect. Instead, she reports about lack of time as playing an inhibiting factor for the team to be fully interconnected. She illustrates this by indicating how time is the most important factor in her lack of contact with another BT.

"She was out in the playground supervising the children on the rare occasions I was in the staffroom and vice versa. So we didn't see each other much at all."

$<<$ Figure-5>>

For centrality, Nina's normalised out-degree and in-degree of 1 indicate that she has nominated everyone in her team as people she has had contact with for work-related issues, and that everyone has nominated her. These scores show that Nina has a very central position in the network, implying a high degree of access to professional support. The small standard 
deviations for normalised out-degree and in-degree in the network imply that there is not much variation between team members in the extent to which they are connected, corroborating Nina's statement that the entire network is interconnected. This is also reflected in her school's network maps (Figure-4), which show that most nodes are of equal size, and therefore similarly to Nina have high centrality scores. Nina's central position is confirmed in the interview data, as she argues that she has work-related contact with all of the team members. She indicates that she actively approaches her colleagues for work-related issues, and considers these encounters as opportunities to grow.

"I actively ask my colleagues things: 'How would you do this or that? Besides, it's a learning experience, isn't it: finding out who I can and can't ask about these things. It's all about trial and error. Nothing ventured, nothing gained, right? You might look stupid, but so be it. I'd rather ask questions a bit too often than do something wrong."

Nina also talks about those factors that inhibit or support her to professionally connect with her colleagues. Specifically, she stresses the staffroom as a place where lots of interactions take place. Nina further argues that she does not have frequent professional contact with the teachers that are not regularly present in the staffroom during breaks, because they stay in their classroom to work, or because they work part-time.

Her knowledge on whom she can approach for certain expertise in the team as well as the accessibility of people are also important factors for Nina's professional contact. Regarding the latter, she emphasises that even though the principal is busy, he often walks by her classroom to ask if she has any issues she wants to talk to him about. Finally, Nina also states that physical proximity is an important supporting factor for engaging in work-related contact.

"Physical location is important: I'll mostly ask questions and have contact with the colleagues whose classroom is nearby.” 
Jasmine indicates that she has had work-related contact with $50 \%$ of the team members. In turn, she is nominated by $58.3 \%$ of her colleagues. These scores reveal that Jasmine's position is less central than Nina's. Moreover, similar to Nina's network, the standard deviations of normalised in-degree and out-degree indicate that there is not much variation between team members in the extent to which they are connected (Table-2). The scores, however, are slightly higher than in Nina's case, meaning that in Jasmine's network some team members are more central than others, while in Nina's network work-related contact is more evenly dispersed. Again, the network maps (Figure-4/5) illustrate these findings. Specifically, the network maps reveal that in Jasmine's school network the size of the nodes show more variation compared to Nina's school network. Moreover, in Golden Oak's network maps, Jasmine's node is among the smallest, revealing her position to be less central than many others in the team. The interview confirms these results. Jasmine argues that a lot of professional exchange between team members takes place, but that she often felt unsupported.

"I really felt that I had to figure out a lot of things on my own. Things to do with organisation and teaching methods in particular."

She highlights that some team members supported her professionally, but that others assumed she did not need help anymore because she was in her second year in the school. Jasmine mainly refers to a lack of professional support by her parallel colleague (i.e., colleague that teaches in the same year), whom she considers to be rather inaccessible.

"She didn't really look out for me. Most of the time I had to figure things out for myself."

Furthermore, next to lack of time and colleagues whom are not open for questions, Jasmine points to two other inhibiting factors for engaging in work-related contact. First, she states that she did not often reach out to her team members, mainly because she stayed in her classroom 
during breaks and did not want her colleagues to think of her as incapable. Second, Jasmine points to the negative effect of her classroom's physical location.

"My classroom is on the top floor of the building. The team members from downstairs never have to be on that floor, because there is nothing there they need. The principal's office, the staff room are all downstairs. So, if you're upstairs nobody ever comes and puts their head round the door."

\section{Network content}

Table-3 shows that Nina is provided with professional support for a broad array of challenges. Moreover, she receives support for these challenges from several colleagues, allowing her to make use of a range of tips, suggestions and ideas on how to tackle them. Jasmine also receives support for certain issues, however, the support is limited in number of colleagues, and often lacks applicability to her classroom practice. Below we discuss the content of the professional support.

$<<$ Table-3>>

Nina showed clear insight into her network, and the location of the expertise in the team. When she has a work-related concern, she will formulate a concrete question and look for a colleague whom she thinks will be most suitable to provide an answer. Her conscious and thoughtful way of networking cause her to receive useful support for several challenges from those people that have the expertise to help her out. In this respect, for dealing with problems of individual pupils and individual differences in the classroom she most frequently asks for support from the special educational needs (SEN) coordinator. Specifically for the latter, she also actively engages with the teacher from the year below, as she is familiar with the pupils and their competences. Furthermore, with respect to teaching materials, she reaches out to the 
SEN teacher and two classroom teachers, and for classroom management and disciplinary issues, Nina contacts the classroom teachers and the principal.

"There was a child who had a cookie covered in chocolate, but the rule is that they can't bring those kinds of cookies to school. He hadn't eaten it yet, but it was in his desk and that isn't allowed either. Was I supposed to confiscate it? Could I throw it in the waste paper basket or should I take it home? I didn't know what to do. So I spoke to the principal and he gave me advice."

For support for instructional and assessment strategies, the classroom teacher of the year below and the principal are most frequently contacted by Nina. The former because she knows the pupils and as such the strategies they prefer and understand, the latter because he has a lot of experience with the subject matter of Nina's year. Concerning communication with parents, Nina reaches out to and receives support from the principal and one of the classroom teachers that knows her parents' pupils well.

"Some colleagues share stories about parent-teacher conferences, and they warn me about certain situations. Reese, for example, told me that I should be prepared for some of the parents. Which is a warning that is welcome. It is good to know that certain parents are very actively involved in their child's development. And that other parents aren't that involved. Those are the kind of things you need to know before parents' evening."

Finally, for organising the class work she mostly contacts and is helped out by the teacher from the same grade, the principal and another BT. Together with the former she works on long-term planning and schedules concerning the curriculum, while the principal helps her out with timemanagement and the other BT shares suggestions on managing the workload.

Jasmine asked some teachers for advice, however, she indicates that she did not always signify her need for help. In this respect, the advice she received was not always applicable or 
sufficiently specific to put into practice. Furthermore, as her main parallel colleague was inaccessible, she did not receive any guidance concerning reducing the workload, something Jasmine struggled with and deems a main factor for her leaving the job.

"If I had had a bit more, erm, if she [parallel colleague] had been a bit more open to questions, I might have asked her: 'How did you do that?' or 'What's the best way to deal with that?' (...) For example: 'How should I organise my lessons so the children can work more independently and I do not have to correct their math books by myself, after work hours?'”

With respect to the other aspects of organisational class work, namely working on planning and time-management, Jasmine notes that she had regular meetings with one of her other parallel colleagues. In these meetings they made sure their work and teaching in the different classes were aligned. Furthermore, for instructional and assessment strategies, one of the classroom teachers, the SEN teacher and the principal offer support. Jasmine explains, however, that her interactions with the principal-even though well-meant-consisted of an overload of information concerning these strategies, out of which she was unable to filter what was most important.

"She often gave lots of tips. All of them were well meant. But there were so many that I couldn't filter out the important ones. Not all of them were applicable or useful either."

Additionally, Jasmine only reported support for communication with parents, differentiated instruction, and dealing with problems of individual students from the SEN coordinator during the extra hours she supported Jasmine. Nevertheless, the frequency of her professional encounters with this colleague are low, as she and her main parallel colleague had to share these extra support hours. Finally, Jasmine reports that she received (advice on) teaching materials from one of the classroom teachers. 


\subsection{RQ2: The relationship between BTs' network and job attitudes}

The results of RQ1 revealed that Nina, as the BT with the highest job attitudes' scores, has more access to professional collegial support and receives more varied support from more colleagues than Jasmine, the BT with the lowest job attitudes' scores.

Asking Nina to discuss her job attitude scores, she states that feeling satisfied with the job highly depends on the colleagues and how supportive they are. She further stipulates that

"I really like working here. In terms of work place... I couldn't have wished for better."

Moreover, the supportive atmosphere at school makes her feel welcome and part of the team, and as such contributes to her affective commitment to the school. She even states that after a vacation she feels like coming home. Finally, regarding intrinsic motivation to teach, Nina reports that

"It's simple. I just really like teaching. And that motivation is contagious. If your colleagues are motivated, well, then you are too."

Nina concludes that the team and their professional support are important in how she experiences the job. Particularly, she states that:

"Your team, your colleagues, really make or break your experience of the job."

"I believe a close and enthusiastic team that supports each other for all kinds of stuff is extremely important."

Figure-3 demonstrates that Jasmine's job attitudes' scores are noticeably lower than Nina's. Jasmine argues that she loves working with children, but that several aspects of the job have contributed to a lower job satisfaction. Specifically, she stipulates the high work load, not being appreciated by several of the children, parents and colleagues, and not being able to get the pleasure she expected from teaching. 
"It's something I loved to do, working with children, teaching and so forth. I really liked that. But everything that came on top of that. That became too much for me, all the extra work. And it wasn't always appreciated, by parents, children, colleagues ... And in the end, not even by myself."

Regarding affective commitment to the school, she has the impression that she was part of the team, but did not always get the professional support she needed. Finally, Jasmine states that her motivation for teaching had become more external:

"I wasn't really motivated to be a teacher anymore, it was more about wanting to do good. I want to do good for others. (...) My motivation comes from that responsibility, rather than from me wanting it. Rather than me wanting to be a teacher. I want to be there for the children, because that's the choice I made. And I really want to excel at that. But not really because I like the job so much. Not for that reason."

The interview results reveal that several issues, such as the high workload, experiencing stress, time management and not feeling appreciated, negatively affected Jasmine's experiences of the job, but that the lack of support regarding these issues is a determining factor for her recent exit. She argues that:

"If there had been anyone this year who'd offered me a bit more support, who had helped me with planning my lessons, or managing my time or whatever. Or scheduling tests. Well, I don't know. I just think it would have been easier for me. I think I would have been more enthusiastic about going back to teach."

\section{Discussion}


Based on the results, several topics can be discussed. The first topic concerns the slightly higher cohesiveness scores for Nina's school network when compared to Jasmine's. Following Coleman (1988), this implies that Nina's team members are to a larger extent interconnected, facilitating the flow of, and access to, professional support. The interview data suggest that the principal plays an important role in the team's interconnectedness. This finding supports previous research, which found that principals can be facilitators of a supportive culture, and in turn, positively influence BTs' choice to remain in the profession (Brown \& Wynn, 2009; Hopkins \& Spillane, 2014).

Second, the results indicate that Nina has a more central position than Jasmine, which based on the work of Burt (2000) suggests that Nina has more access to the network's resources. The results showed that Nina actively initiates contact and is approached by her colleagues for work-related issues. Conversely, Jasmine, indicates feeling inhibited in terms of engaging in work-related contact, and experiences a lack of engagement coming from her colleagues for work-related issues. Several factors hinder Jasmine from engaging in work-related contact. The first factor is that she does not feel safe admitting that she needs help. This finding corroborates research from Cross, Parker, Prusak, and Borgatti (2005), who found that feeling safe admitting a lack of expertise is a prerequisite for managers to engage in contact with someone. High workload appears to be a second inhibiting factor, and has been considered a major challenge in previous research (Kyriacou \& Kunc, 2007). The third factor that hindered Jasmine concerned certain colleagues' inaccessibility and their unwillingness to share expertise. Gaikhorst, Beishuizen, Korstjens, and Volman (2014) found that the accessibility of colleagues, and openness to discuss their experiences, are important for BTs. The final inhibiting factor for Jasmine is physical proximity. This confirms earlier research stressing that the smaller the physical and perceived distance between individuals, the more likely they are to form ties (e.g., Coburn, Choi, \& Mata, 2010; Le Cornu, 2013). 
The third topic involves the content of BTs' professional collegial support. Even though both teachers receive support for a variety of the most commonly perceived challenges of BTs by Veenman (1984), for Jasmine, this support was limited in terms of frequency and number of colleagues. Previous studies reveal that receiving limited input from a small number of people results in poorer information, and may cause a lack of further teacher development (Ericsson, 2006; Smither, London, \& Reilly, 2005; Van Waes, Van den Bossche, Moolenaar, De Maeyer, \& Van Petegem, 2015). In this respect, the present study confirms Struyve et al.'s (2016) finding that BTs need support from a diverse network of colleagues, rather than limiting this support to help from a single appointed mentor.

Further pertaining to network content, this study shows that BTs are in need of and receive support for a multitude of challenges. Compared with their experienced counterparts, BTs experience more difficulties with, e.g., differentiated instruction (Meister \& Melnick, 2003) and engaging in valuable parent-teacher relationships (Epstein, 2013). Moreover, BTs also need to get acquainted with the school culture and become part of the school team (Author et al., 2013). This combination of challenges makes teachers' first years in practice complex as well as demanding. In this respect, BTs feel the need to expand their professional networks, as they want to discuss these challenges and develop their teaching practice (Kilgore \& Griffin, 1998; Van Waes et al., 2015). The study of Struyve et al. (2016) showed that while being socially connected with and professionally supported by team members matters for both beginning and experienced teachers, the former gain significantly more advantage from their relationships with colleagues. By connecting to, and feeling supported by, their colleagues BTs can find their place in the team (Ewing \& Manuel, 2005), and develop their teacher identity (Rippon \& Martin, 2006).

Another finding regarding network content is that neither Nina nor Jasmine mentioned receiving support for motivating pupils, although they consider this to be challenging. A 
possible explanation may be that, compared to challenges such as classroom management or assessment strategies, motivating pupils is a topic that remains a difficulty throughout teachers' careers (e.g., Aelterman, Vansteenkiste, Van Keer, \& Haerens, 2016). Consequently, experienced teachers may feel inhibited to provide advice on this topic.

Interestingly, the results suggest that access to professional support is dependent on the interplay between the BT and their network of colleagues. Nina actively approaches her colleagues and purposefully reaches out to people who have the expertise to help address a specific challenge. She is not only aware of the location of expertise in the team (i.e., relational knowledge, namely, knowing what someone else knows; Cross, Parker, \& Borgatti, 2002), but also acts on this knowledge to actively shape her support network. She knows how to manoeuvre the network to acquire useful information for her development as a teacher. Moolenaar et al. (2014) found that teachers with high levels of network intentionality-defined as a type of agency through which teachers consciously shape their network (e.g., actively reaching out to others)-have more access to network resources. In particular, they found a positive relationship between network intentionality and having a central network position. Our explorative analyses of Nina's case confirm this hypothesis. Moreover, Nina stipulates the school's supportive culture, which seems to strengthen her active role in shaping a support network even further. Jasmine's case tells a different story. She indicates not always signifying her need for help. The absence of a specific question or call for help seems to contribute to a lack of helpful advice, and rather leads to vague tips which are not always applicable. This supports the idea that explicitly asking for help is an important condition for receiving aid from colleagues (Author, 2006). Additionally, Jasmine reports feeling inhibited to professionally connect with her colleagues, due to some colleagues' inaccessibility. This finding underscores the interplay between BTs and their school network. Agency in shaping a supportive network 
is the responsibility of the BT; however, this agency can be supported or constrained by the school network (De Laat, 2006; Haythornthwaite \& De Laat, 2012).

The final topic is the relationship between BTs' network and job attitudes. The explorative results appear to suggest that when BTs are able to professionally engage with their colleagues, and receive support from a diverse number of colleagues and for a variety of issues, this positively relates to their job attitudes and, by extension, their intention to remain in the profession. These explorative results corroborate earlier research that shows a positive relationship between being professionally supported and retaining teachers in the profession (e.g., Rippon \& Martin, 2006). Moreover, our results seem to confirm Newberry and Allsop's (2017) findings that not the perceived challenges, but rather, the lack of support for these challenges signify a main reason for departure. This result highlights that in a high intensity situation such as the induction period, relationships do matter, and should receive attention.

An important remark is that the relationship between teachers' support networks and job attitudes is not necessarily unidirectional. Besides studying the influence of BTs' support networks on how teachers feel and think about their profession and school, we should also consider that teachers' job attitudes may affect their support networks. For example, previous research has stipulated that people who are committed, are more likely to invest effort in their job as they want to help their organisation in goal attainment (Somech \& Bogler, 2002; Yousef, 2000). In this respect, several scholars found that organisational commitment is positively related to people's willingness to share knowledge in their team (e.g., Kelloway \& Barling, 2000; Van Den Hooff \& Ridder, 2004). Along these lines, we may expect that BTs whose commitment has diminished, may invest less effort in building a strong support network. Applied to this study, Jasmine's lower job attitude scores may also have been a reason that prompted her to stay in her classroom during breaks instead of reaching out to her colleagues for support. Yet, the directionality of the relationship between job attitudes and support 
networks was not at the core of our study, as we set out to understand how support networks may affect BTs' job attitudes, because we believe that these networks may provide valuable leverage that allow for targeted interventions to support BTs and their team in combating teacher attrition. More work is needed to parse out how teachers' job attitudes and support networks are mutually interdependent.

\section{Limitations and further research}

This study has certain limitations. First, generalisation is limited, given the study's small sample. Further research that can validate the findings in larger and more diverse samples (e.g., other educational levels) is needed. However, albeit the lack of generalisation, contrasting cases can produce new knowledge (Palinkas et al., 2015) and enable an in-depth understanding (Harrison, Birks, Franklin, \& Mills, 2017), as was shown in this study regarding BTs' collegial networks and their relationship to job attitudes. In this respect, the ultimate goal of the contextdependent knowledge created by the cases is that we can learn from them (Eysenck, 1976; Flyvbjerg, 2011).

Second, the dynamic nature of social networks (Kilduff \& Tsai, 2003) was not considered as data were collected at one measurement moment. Additionally, the study explored the relation between BTs' networks and their job attitudes; however, we must be careful with causal claims. Further research embedded in a longitudinal design is needed.

Third, following Kilduff and Krackhardt (1994) who point to the added value of using an ego and whole-school approach, the current study combined both to provide a more complete picture. However, the results must be interpreted carefully, as they are self-reported in nature. Further research may be able to triangulate the quantitative network data by observing teachers' interactions (Coburn et al., 2012), and the qualitative data by interviewing multiple data sources (e.g., colleagues, principal) so that the BTs and their colleagues' interpretations could be 
compared. In the present study, BTs' perceptions of their network were particularly interesting, as behaviour changes based on teachers' perceptions of their environment (Hommes et al., 2012).

Fourth, the BTs were only asked to report on their primary school team members. Yet, earlier research has shown that professional connections outside of the team (e.g., family, external professionals) can play an important role (Mansfield et al., 2014). Further research could include these actors in the analyses.

Fifth, the focus of our study was not individual differences between teachers, however, we acknowledge that future research could extend this work by considering these in the analyses. The study's cases have suggested that access to professional support depends on the interplay between the BT and their network of colleagues. In further research, the interplay between BTs and their environment, and how this affects their job attitudes could be unravelled more thoroughly. In research in other contexts, scholars have found a link between people's personality and the extent to which they occupy a central network position (Klein, Lim, Saltz, \& Maeyer, 2004; Mehra, Kilduff, \& Brass, 2001). In line with these studies, the link between personality, agency and the network could be explored in the context of BTs' first years in practice. Furthermore, zooming in on personality and/or other individual characteristics could uncover interesting findings regarding the link to job attitudes. In the current study, the BTs have emphasised the importance of professional support in their job attitudes. However, some teachers might thrive when they are not constantly in professional contact with others. In this respect, personality might nuance the study's finding that higher job attitudes are always linked with more access to professional support.

Sixth, the study's main focus was put on positive ties (the presence of professional relationships) and their favourable outcomes. However, social networks are no "unmixed blessing" (Portes, 1998). Research wherein explicit attention is aimed at the 'dark side' of the 
network, or put differently focuses on toxic aspects such as destructive conflicts are needed (Borgatti \& Foster, 2003; de Lima, 2010). Such research is indispensable, as negative relationships may have more far-reaching effects than their positive counterparts (Everett \& Borgatti, 2014). This could mean that when BTs have destructive ties, this may negatively affect their job attitudes, which may outweigh the positive effects of their support ties.

\section{Implications}

The study's findings illustrate that interacting with one another for work-related issues, and being professionally supported, is dependent on the interplay between BTs and their network of colleagues. BTs should be stimulated into actively seeking out contact with their colleagues (Fox \& Wilson, 2015), while their colleagues have to be prepared to share their expertise (Gaikhorst et al., 2014). In stimulating BTs to engage with colleagues that can help to address their challenges, we suggest investing in increasing their relational knowledge (Cross, Parker, \& Borgatti, 2002) and network intentionality (Moolenaar et al., 2014). Regarding the former, we argue that when BTs are aware of the expertise in a team, they can be supported more efficiently. Making social capital and its flow through the network more transparent (Moolenaar, 2011) can be achieved by visualising the network. Specifically, network maps can be used as a tool for increasing expertise transparency (Baker-Doyle \& Yoon, 2010; Wilson \& Demetriou, 2007). Additionally, based on previous research (e.g., Moolenaar et al., 2014), we suggest strengthening teachers' skills in intentionally and actively shaping their network and help them act on their network awareness. In this respect, research investigating if and how network intentionality as a competence can be fostered, is needed. Furthermore, in terms of promoting a team to share their expertise with the BT, the principal appears to play an important role. The principal can stimulate support in a team by, e.g., creating a welcoming staffroom (Struyve et al., 2016), promoting collective action and mutual responsibility (Minckler, 2014), 
and organising formal support structures (e.g., professional learning communities) (Struyve et al., 2016; Woodland \& Mazur, 2019). Woodland and Mazur (2019) found that formal support networks arranged by the principal were positive predictors of informal instrumental ties between teachers and as such played a key role in teachers' access to social capital. These initiatives for a team in which open communication becomes self-evident may also counterbalance BTs' inhibition to engage in work-related contact. Finally, the findings revealed physical proximity to be another inhibiting factor. A reasonable approach may be to provide the BT with a classroom at the heart of the school, and as such, literally situating them at the centre of their team. 


\section{References}

Author et al. (2002). [details removed for peer review]

Author (2006). [details removed for peer review]

Author et al. (2018). [details removed for peer review]

Aelterman, A., Meysman, H., Troch, F., Vanlaer, O., \& Verkens, A. (2008). Een nieuw profiel voor de leraar kleuteronderwijs en lager onderwijs. Hoe worden leraren daartoe gevormd? [A new profile for teachers in pre-school and primary education. How are teachers formed to meet this profile?] Brussels: Flemish Department of Education.

Aelterman, N., Vansteenkiste, M., Van Keer, H., \& Haerens, L. (2016). Changing teachers' beliefs regarding autonomy support and structure: The role of experienced psychological need satisfaction in teacher training. Psychology of Sport and Exercise, 23, 64-72. doi: 10.1016/j.psychsport.2015.10.007

Baarda, D., de Goede, M., \& Teunissen, J. (2005). Basisboek voor kwalitatief onderzoek [Basic manual for qualitative research]. Groningen-Houten: Noordhoff Uitgevers.

Baker-Doyle, K. J. (2010). Beyond the labor market paradigm: A social network perspective on teacher recruitment and retention. Education Policy Analysis Archives, 18(26). doi: 10.14507/epaa.v18n26.2010

Baker-Doyle, K. J. (2012). First-year teachers' support networks: Intentional professional networks and diverse professional allies. The New Educator, 8(1), 65-85. doi: 10.1080/1547688X.2012.641870

Baker-Doyle, K. J. (2015). Stories in networks and networks in stories: A tri-modal model for mixed-methods social network research on teachers. International Journal of Research \& Method in Education, 38(1), 72-82. doi: 10.1080/1743727X.2014.911838

Baker-Doyle, K. J., \& Yoon, S. A. (2010). Making expertise transparent. Using technology to strengthen social networks in teacher professional development. In A. J. Daly (Ed.), Social Network Theory and Educational Change (pp. 115-126). Cambridge: Harvard Education Press.

Boeije, H., 't Hart, H., \& Hox, J. (2009). Onderzoeksmethoden [Research methods]. Amsterdam: Boom Lemma Uitgevers.

Borgatti, S. P. (2002). Netdraw network visualisation. Harvard, MA: Analytic Technologies.

Borgatti, S. P. (2005). Centrality and network flow. Social Networks, 27(1), 55-71. doi: 10.1016/j.socnet.2004.11.008

Borgatti, S. P., Everett, M. G., \& Freeman, L. C. (2002). Ucinet 6 for Windows: Software for Social Network Analysis. Harvard, MA: Analytic Technologies.

Borgatti, S. P., Everett, M. G., \& Johnson, J. C. (2013). Analyzing social networks. London: Sage.

Borgatti, S. P., \& Foster, P. C. (2003). The network paradigm in organizational research: A review and typology. Journal of Management, 29(6), 991-1013. doi: 10.1016/S01492063(03)00087-4 
Borgatti, S. P., \& Ofem, B. (2010). Overview: Social network theory and analysis. In A. J. Daly (Ed.), Social Network Theory and Educational Change (pp. 17-29). Cambridge: Harvard Education Press.

Borman, G. D., \& Dowling, N. M. (2008). Teacher attrition and retention: A meta-analytic and narrative review of the research. Review of Educational Research, 78(3), 367-409. doi: $10.3102 / 0034654308321455$

Braun, V., \& Clarke, V. (2006). Using thematic analysis in psychology. Qualitative Research in Psychology, 3(2), 77-101. doi: 10.1191/1478088706qp063oa

Brown, K. M., \& Wynn, S. R. (2009). Finding, supporting, and keeping: The role of the principal in teacher retention issues. Leadership and Policy in Schools, 8(1), 37-63. doi: 10.1080/15700760701817371

Burt, R. S. (2000). The network structure of social capital. Research in Organizational Behaviour, 22, 345-423. doi: 10.1016/S0191-3085(00)22009-1

Cameron, D. L. (2017). Teacher preparation for inclusion in Norway: A study of beliefs, skills and intended practices. International Journal of Inclusive Education, 21(10), 10281044. doi: 10.1080/13603116.2017.1326177

Caprara, G. V., Barbaranelli, C., Borgogni, L., \& Steca, P. (2003). Efficacy beliefs as determinants of teachers' job satisfaction. Journal of Educational Psychology, 95(4), 821-832. doi: 10.1037/0022-0663.95.4.821

Carmeli, A., \& Weisberg, J. (2006). Exploring turnover intentions among three professional groups of employees. Human Resource Development International, 9(2), 191-206. doi: 10.1080/13678860600616305

Carrington, P. J., Scott, J., \& Wasserman, S. (2005). Models and methods in social network analysis. New York: Cambridge University Press.

Coburn, C. E., Choi, L., \& Mata, W. (2010). "I would go to her because her mind is math". Network formation in the context of a district-based mathematics reform. In A. J. Daly (Ed.), Social Network Theory and Educational Change (pp. 33-50). Cambridge: Harvard Education Press.

Coburn, C. E., \& Russell, J. L. (2008). District policy and teachers' social networks. Educational Evaluation and Policy Analysis, 30(3), 203-235. doi: 10.3102/0162373708321829

Coburn, C., Russell, J. L., Kaufman, J. H., \& Stein, M. K. (2012). Supporting sustainability: Teachers advice networks and ambitious instructional reform. American Journal of Education, 119(1), 137-182. doi: 10.1086/667699

Cochran-Smith, M., \& Power, C. (2013). Preparing teachers for diversity: A global issue. Modi Migranti, 5(2), 81-98.

Coleman, J. S. (1988). Free riders and zealots: The role of social networks. Sociological Theory, 6(1), 52-57. doi: 10.2307/201913

Craig, C. J. (2017). International teacher attrition: Multiperspective views [Special issue]. Teachers and Teaching: Theory and Practice, 23(8), 859-862. doi: 10.1080/13540602.2017.1360860

Cross, R., Parker, A., \& Borgatti, S. P. (2002). A bird's-eye view: Using social network 
analysis to improve knowledge creation and sharing. Retrieved on 5 January, 2019 from: https://www-07.ibm.com/services/hk/strategy/e_strategy/social_network.html

Cross, R., Parker, A., Prusak, L., \& Borgatti, S. P. (2005). Knowing what we know: Supporting knowledge creation and sharing in social networks. Creating Value with Knowledge: Insights from the IBM Institute for Business Value, 30(2), 100-120. doi: 10.1093/0195165128.003.0005

Crossley, N. (2010). The social world of the network. Combining qualitative and quantitative elements in social network analysis. Sociologica, 1, 1-34. doi: 10.2383/32049

Crossley, N., Bellotti, E., Edwards, G., Everett, M. G., Koskinen, J., \& Tranmer, M. (2015). Social network analysis for ego-nets. London: Sage.

Cummings, T. G., \& Bigelow, J. (1976). Satisfaction, job involvement, and intrinsic motivation: An extension of Lawler and Hall's factor analysis. Journal of Applied Psychology, 61(4), 523-525. doi: 10.1037/0021-9010.61.4.523

De Laat, M. (2006). Networked learning. Apeldoorn: Politie Academie.

de Lima, J. Á. (2010). Thinking more deeply about networks in education. Journal of Educational Change, 11(1), 1-21. doi: 10.1007/s10833-008-9099-1

Degenne, A., \& Forsé, M. (1999). Introducing social networks. London: Sage.

Edwards, G. (2010). Mixed-Method Approaches to Social Network Analysis. ESRC National Centre for Research Methods, NCRM.015, 1-30. doi: 10.1108/17465640910978391

Epstein, J. L. (2013). Ready or not? Preparing future education for school, family and community partnerships. Teaching Education, 24(2), 115-118. doi: $10.1080 / 10476210.2013 .786887$

Ericsson, K. A. (2006). The influence of experience and deliberate practice on the development of superior expert performance. In K. A. Ericsson, N. Charness, R. R. Hoffman, \& P. J. Feltovich (Eds.), The Cambridge handbook of expertise and expert performance (pp. 685-706). New York: Cambridge University Press.

Everett, M., \& Borgatti, S.P. (2014). Networks containing negative ties. Social Networks, 38(3), 111-120. doi: 10.1016/j.socnet.2014.03.005

Ewing, R., \& Manuel, J. (2005). Retaining quality early career teachers in the profession: New teacher narratives. Change: Transformations in Education, 8(1), 1-16.

Eysenck, H. J. (1976). Introduction. In H. J. Eysenck (Ed.), Case studies in behaviour therapy (pp. 1-15). London: Routledge.

Fantilli, R. D., \& McDougall, D. E. (2009). A study of novice teachers: Challenges and supports in the first years. Teaching and Teacher Education, 25(6), 814-825. doi: 10.1016/j.tate.2009.02.021

Flyvbjerg, B. (2011). Case study. In N. K. Denzin and Y. S. Lincoln (Eds.), The Sage handbook of qualitative research (4th ed., pp. 301-316). Thousand Oaks, CA: Sage.

Fox, A. R. C., \& Wilson, E. G. (2015). Networking and the development of professionals: Beginning teachers building social capital. Teaching and Teacher Education, 47, 93107. doi: 10.1016/j.tate.2014.12.004 
Gaikhorst, L., Beishuizen, J. J., Korstjens, I. M., \& Volman, M. L. L. (2014). Induction of beginning teachers in urban environments: An exploration of the support structure and culture for beginning teachers at primary schools needed to improve retention of primary school teachers. Teaching and Teacher Education, 42, 23-33. doi: 10.1016/j.tate.2014.04.006

George, J., \& Jones, G. (1999). Understanding and managing organizational behavior. Reading, MA: Addison-Wesley.

Glaser, B. G., \& Strauss, A. L. (1967). The discovery of grounded theory: Strategies for qualitative research. Chicago, IL: Aldine Publishing Company.

Goddard, J. T., \& Foster, R.Y. (2001). The experiences of neophyte teachers: A critical constructivist assessment. Teaching and Teacher Education, 17(3), 349-365. doi: 10.1016/S0742-051X(00)00062-7

Harrison, H., Birks, M., Franklin, R., \& Mills, J. (2017). Case study research: Foundations and methodological orientations. Retrieved on 5 January, 2019 from: http://www.qualitative-research.net/index.php/fqs/article/view/2655/4079

Hartley, J. (2004). Case study research. In C. Cassell, \& S. Gillian (Eds.), Essential guide to qualitative methods in organizational research (pp. 323-333). London: Sage.

Haythornthwaite, C., \& De Laat, M. (2012). Social network informed design for learning with educational technology. In A. Olofson, \& O. Lindberg (Eds.), Informed design of educational technologies in higher education: Enhanced learning and teaching (pp. 352-374). Hershey: IGI-Global.

Henry, G. T., Bastian, K. C., \& Fortner, C. K. (2011). Stayers and leavers: Early-career teacher effectiveness and attrition. Educational Researcher, 40(6), 271-280. doi: 10.3102/0013189X11419042

Holloway, J. H. (2000). Preparing teachers for differentiated instruction. Educational Leadership, 58(1), 82-83.

Hommes, J., Rienties, B., de Grave, W., Bos, G., Schuwirth, L., \& Scherpbier, A. (2012). Visualising the invisible: A network approach to reveal the informal social side of student learning. Advances in Health Sciences Education, 17(5), 743-757. doi: $10.1007 / \mathrm{s} 10459-012-9349-0$

Hopkins, M., \& Spillane, J. P. (2014). Schoolhouse teacher educators: Structuring beginning teachers' opportunities to learn about instruction. Journal of Teacher Education, 65(4), 327-339. doi: 10.1177/0022487114534483

Huisman, M., \& Steglich, C. E. G. (2008). Treatment of non-response in longitudinal network studies. Social Networks, 30(4), 297-308. doi: 10.1016/j.socnet.2008.04.004

Hunt, J. B., Darling-Hammond, L., Alvarado, A., Bryant, A. L., Castor, B., Chan, I. H., ... Wise, A.E. (2003). No dream denied: A pledge to America's children (Summary report). Washington, DC: National Commission on Teaching and America's Future.

Ibarra, H., \& Andrews, S. B. (1993). Power, social influence, and sense making: Effects of network centrality and proximity on employee perceptions. Administrative Science Quarterly, 38(2), 277-303. doi: 10.2307/2393414

Ingersoll, R. M. (2001). Teacher turnover and teacher shortages: An organizational analysis. 
American Educational Research Journal, 38(3), 499-534. doi:

$10.3102 / 00028312038003499$

Ingersoll, R. M., \& Strong, M. (2011). The impact of induction and mentoring programs for beginning teachers: A critical review of the research. Review of Educational Research, 81(2), 201-233. doi: 10.3102/0034654311403323

Kelloway, E. K., \& Barling, J. (2000). Knowledge work as organizational behavior. International Journal of Management Reviews, 2(3), 287-304. doi: 10.1111/14682370.00042

Kersaint, G., Lewis, J., Potter, R., \& Meisels, G. (2007). Why teachers leave: Factors that influence retention and resignation. Teaching and Teacher Education, 23(6), 775-794. doi: 10.1016/j.tate.2005.12.004

Kilduff, M., \& Krackhardt, D. (1994). Bringing the individual back in: A structural analysis of the internal market for reputation in organizations. Academy of Management Journal, 37(1), 87-108. doi: 10.5465/256771

Kilduff, M., \& Tsai, W. (2003). Social networks and organizations. London: Sage.

Kilgore, K. L., \& Griffin, C. C. (1998). Beginning special educators: Problems of practice and the influence of school context. Teacher Education and Special Education, 21(3), 155-173. doi: 10.1177/088840649802100302

Klein, K. J., Lim, B.-C., Saltz, J. L., \& Maeyer, D. M. (2004). How do they get there? An examination of the antecedents of centrality in team networks. Academy of Management Journal, 47(6), 952-963. doi: 10.5465/20159634

Kyriacou, C., \& Kunc, R. (2007). Beginning teachers' expectations of teaching. Teaching and Teacher Education, 23(8), 1246-1257. doi: 10.1016/j.tate.2006.06.002

Lachman, R., \& Aranya, N. (1986). Job attitudes and turnover intentions among professionals in different work settings. Organization Studies, 7(3), 279-293. doi: $10.1177 / 017084068600700305$

Le Cornu, R. (2013). Building early career teacher resilience: The role of relationships. Australian Journal of Teacher Education, 38(4), 1-16. doi: 10.14221/ajte.2013v38n4.4

Leana, C. R., \& Van Buren, H. J. I. (1999). Organizational social capital and employment practices. The Academy of Management Review, 24(3), 538-555. doi: 10.1080/0142569032000070137

Levy, H. M. (2008). Meeting the needs of all students through differentiated instruction. Helping every child reach and exceed standards. Clearing House, 81(4), 161-164. doi: 10.3200/TCHS.81.4.161-164

Mansfield, C., Beltman, S., \& Price, A. (2014). 'I"m coming back again!' The resilience process of early career teachers. Teachers and Teaching: Theory and Practice, 20(5), 547-567. doi: 10.1080/13540602.2014.937958

McInerney, D. M., Ganotice, F. A., King, R. B., Marsh, H. W., \& Morin, A. J. S. (2015). Exploring commitment and turnover intentions among teachers: What we can learn from Hong Kong teachers. Teaching and Teacher Education, 52, 11-23. doi: 10.1016/j.tate.2015.08.004

Mehra, A., Kilduff, M., \& Brass, D. J. (2001). The social networks of high and low self- 
monitors: Implications for workplace performance. Administrative Quarterly, 46(1), 121-146. doi: $10.2307 / 2667127$

Meister, D. G., \& Melnick, S. A. (2003). National new teacher study: Beginning teachers' concerns. Action in Teacher Education, 24(4), 87-94. doi: 10.1080/01626620.2003.10463283

Meredith, C. (2017). Connecting the dots. A social network perspective on socialorganizational processes in secondary schools (Unpublished doctoral thesis), University of Leuven, Belgium.

Meyer, J. P., \& Allen, N. J. (1991). A three-component conceptualization of organizational commitment. Human Resource Management Review, 1(1), 61-89. doi: 10.1016/10534822(91)90011-Z

Meyer, J. P., Allen, N. J., \& Smith, C. A. (1993). Commitment to organizations and occupations: Extension and test of a three-component conceptualization. Journal of Applied Psychology, 78(4), 538-551. doi: 10.1037/0021-9010.78.4.538

Meyer, J. P., Stanley, D. J., Herscovitch, L., \& Topolnytsky, L. (2002). Affective, continuance, and normative commitment to the organization: A meta-analysis of antecedents, correlates, and consequences. Journal of Vocational Behavior, 61(1), 2052. doi: $10.1006 /$ jvbe. 2001.1842

Miles, M., \& Huberman, M. (1994). Qualitative data analysis. London: Sage.

Minckler, C. H. (2014). School leadership that builds teacher social capital. Educational Management Administration \& Leadership, 42(5), 657-679. doi: $10.1177 / 1741143213510502$

Moir, E., \& Stobbe, C. (1995). Professional growth for new teachers: Support and assessment through collegial partnerships. Teacher Education Quarterly, 22(4), 83-91.

Moolenaar, N. M. (2011). Het verborgen kapitaal. De kracht van sociale netwerken in Nederlandse basisscholen [The power of social networks in Dutch Primary Schools]. Personeel en Organisatie, 27, 105-124. doi: 10.1017/CBO9781107415324.004

Moolenaar, N. M. (2012). A social network perspective on teacher collaboration in schools: Theory, methodology, and applications. American Journal of Education, 119(1), 7-39. doi: $10.1086 / 667715$

Moolenaar, N. M., Daly, A. J., Cornelissen, L., Liou, Y.-H., Caillier, S., Riordan, R. ... Cohen, A. (2014). Linked to innovation: Shaping an innovative climate through network intentionality and educators' social network position. Journal of Educational Change, 15(2), 99-123. doi: 10.1007/s10833-014-9230-4

Moolenaar, N. M., Sleegers, P. J. C., \& Daly, A. J. (2011). Ties with potential: Social network structure and innovative climate in Dutch schools. Teachers College Record, 113(9), 1983-2017.

Moolenaar, N. M., Sleegers, P. J. C., \& Daly, A. J. (2012). Teaming up: Linking collaboration networks, collective efficacy, and student achievement. Teaching and Teacher Education, 28(2), 251-262. doi: 10.1016/j.tate.2011.10.001

Mowday, R. T., Steers, R. M., \& Porter, L. W. (1979). The measurement of organizational commitment. Journal of Vocational Behavior, 14(2), 224-247. doi: 10.1016/0001- 
8791(79)90072-1

Newberry, M., \& Allsop, Y. (2017). Teacher attrition in the USA: the relational elements in a Utah case study. Teachers and Teaching: Theory and Practice, 23(8), 863-880. doi: 10.1080/13540602.2017.1358705

Odell, S. J. (1986). Induction support of new teachers: A functional approach. Journal of Teacher Education, 37(1), 26-29. doi: 10.1177/002248718603700106

OECD [The Organization for Economic Cooperation and Development] (2005). Teachers matter. Attracting, developing and retaining effective teachers. OECD Publishing: Paris.

Palinkas, L. A., Horwitz, S. M., Green, C. A., Wisdom, J. P., Duan, N., \& Hoagwood, K. (2015). Purposeful sampling for qualitative data collection and analysis in mixed method implementation research. Administration and Policy in Mental Health and Mental Health Services Research, 42(5), 533-544. doi: 10.1007/s10488-013-0528-y

Penuel, W., Riel, M., Krause, A., \& Frank, K. (2009). Analyzing teachers' professional interactions in a school as social capital: A social network approach. Teachers College Record, 111(1), 124-163.

Pitts, V. V. M., \& Spillane, J. P. J. (2009). Using social network methods to study school leadership. International Journal of Research and Method in Education, 32(2), 185207. doi: 10.1080/17437270902946660

Portes, A. (1998). Social capital: Its origins and applications in modern sociology. Annual Review of Sociology, 24(1), 1-24. doi: 10.1146/annurev.soc.24.1.1

Riehl, C., \& Sipple, J. W. (1996). Making the most of time and talent: Secondary school organizational climates, teaching task environments, and teacher commitment. American Educational Research Journal, 33(4), 873-901. doi: $10.3102 / 00028312033004873$

Rippon, J. H., \& Martin, M. (2006). Call me teacher: The quest of new teachers. Teachers and Teaching: Theory and Practice, 12(3), 305-324. doi: 10.1080/13450600500467605

Ronfeldt, M., Loeb, S., \& Wyckoff, J. (2013). How teacher turnover harms student achievement. American Educational Research Journal, 50(1), 4-36. doi: $10.3102 / 0002831212463813$

Saldaña, J. (2013). The coding manual for qualitative researchers. Los Angeles, CA: Sage.

Scott, J. (2013). Social network analysis. London: Sage.

Skaalvik, E. M., \& Skaalvik, S. (2007). Dimensions of teacher self-efficacy and relations with strain factors, perceived collective teacher efficacy, and teacher burnout. Journal of Educational Psychology, 99(3), 611-625. doi: 10.1037/0022-0663.99.3.611

Skaalvik, E. M., \& Skaalvik, S. (2011). Teacher job satisfaction and motivation to leave the teaching profession: Relations with school context, feeling of belonging, and emotional exhaustion. Teaching and Teacher Education, 27(6), 1029-1038. doi: 10.1016/j.tate.2011.04.001

Smit, R., \& Humpert, W. (2012). Differentiated instruction in small schools. Teaching and Teacher Education, 28(8), 1152-1162. doi: 10.1016/j.tate.2012.07.003 
Smith, P. C., Kendall, L. M., \& Hulin, C. L. (1969). The measurement of satisfaction in work and retirement. Chicago, IL: Rand McNally.

Smither, J. W., London, M., \& Reilly, R. R. (2005). Does performance improve following multisource feedback? A theoretical model, meta-analysis, and review of empirical findings. Personnel Psychology, 58(1), 33-66. doi: 10.1111/j.1744-6570.2005.514_1.x

Snoeck, M., Eisenschmidt, E., Forsthuber, B., Holdsworth, P., Michaelidou, A., Dahl, J., \& Pachler, N. (2010). Developing coherent and system-wide induction programmes for beginning teachers: A handbook for policy makers. Brussels: European Commission.

Soenens, B., Sierens, E., Vansteenkiste, M., Dochy, F., \& Goossens, L. (2012). Psychologically controlling teaching: Examining outcomes, antecedents, and mediators. Journal of Educational Psychology, 104(1), 108-120. doi: $10.1037 / \mathrm{a} 0025742$

Somech, A., \& Bogler, R. (2002). Antecedents and consequences of teacher organisational and professional commitment. Educational Administration Quarterly, 38(4), 555-577. doi: $10.1111 / \mathrm{j} .1750-3639.2008 .00236 . x$

Stansbury, K., \& Zimmerman, J. (2000). Lifelines to the classroom: Designing support for beginning teachers. WestEd, 23(4), 2-16.

Struyve, C., Daly, A., Vandecandelaere, M., Meredith, C., Hannes, K., \& De Fraine, B. (2016). More than a mentor: The role of social connectedness in early career and experienced teachers' intention to leave. Journal of Professional Capital and Community, 1(3), 198-218. doi: 10.1108/JPCC-01-2016-0002

Thomas, A. B. (2007). Supporting new visions for social justice teaching: The potential for professional development networks. Penn GSE Perspectives on Urban Education, 5(1). Retrieved on 5 January, 2019 from: https://urbanedjournal.gse.upenn.edu/archive/volume-5-issue-1-spring-2007

Tschannen-Moran, M., \& Woolfolk Hoy, A. W. (2001). Teacher efficacy: Capturing an elusive construct. Teaching and Teacher Education, 17(7), 783-805. doi: 10.1016/S0742-051X(01)00036-1

Tynjälä, P., \& Heikkinen, H. L. T. (2011). Beginning teachers' transition from pre-service education to working life: Theoretical perspectives and best practices. Zeitschrift Für Erziehungswissenschaft, 14(1), 11-33. doi: 10.1007/s11618-011-0175-6

van den Broeck, A., Vansteenkiste, M., de Witte, H., Lens, W., \& Andriessen, M. (2009). De zelf-determinatie theorie: Kwalitatief goed motiveren op de werkvloer. [The selfdetermination theory: Motivating in the workplace]. Gedrag en Organisatie, 22(4), 316-334.

Van den Hooff, B., \& de Ridder, J. A. (2004). Knowledge sharing in context: The influence of organizational commitment, communication climate and CMC use on knowledge sharing. Journal of Knowledge Management, 8(6), 117-130. doi: 10.1016/j.ijrmhm.2016.09.016

Van Waes, S., Moolenaar, N. M., Daly, A. J., Heldens, H. H. P. F., Donche, V., Van Petegem, P., \& Van den Bossche, P. (2016). The networked instructor: The quality of networks in different stages of professional development. Teaching and Teacher Education, 59, 295-308. doi: 10.1016/j.tate.2016.05.022 
Van Waes, S., Van den Bossche, P., Moolenaar, N. M., De Maeyer, S., \& Van Petegem, P. (2015). Know-who? Linking faculty's networks to stages of instructional development. Higher Education, 70(5), 807-826. doi: 10.1007/s10734-015-9868-8

Vansteenkiste, M., Neyrinck, B., Niemic, C., Soenens, B., De Witte, H., \& Van den Broeck, A. (2007). On the relations among work value orientations, psychological need satisfaction and job outcomes: A self-determination theory approach. Journal of Occupational and Organizational Psychology, 80(2), 251-277. doi: 10.1348/096317906X111024

Veenman, S. (1984). Perceived problems of beginning teachers. Review of Educational Research, 54(2), 143-178. doi: 10.3102/00346543054002143

Wasserman, S., \& Faust, K. (1994). Social network analysis. Methods and applications. New York: Cambridge University Press.

Willemse, T. M., Vloeberghs, L., De Bruïne, E. J., \& Van Eynde, S. (2016). Preparing teachers for family school partnerships: A Dutch and Belgian perspective. Teaching Education, 27(2), 212-228. doi: 10.1080/10476210.2015.1069264

Wilson, E. G., \& Demetriou, H. (2007). New teacher learning: Substantive knowledge and contextual factors. The Curriculum Journal, 18(3), 213-221. doi: $10.1080 / 09585170701589710$

Woodland, R. H., \& Mazur, R. (2019). Of teams and ties: Examining the relationship between formal and informal instructional support networks. Educational Administration Quarterly, 55(1), 42-72. doi: 10.1177/0013161X18785868

Yin, R. (1994). Case study research: Design and methods. Beverly Hills, CA: Sage.

Yousef, D. A. (2000). Organizational commitment: A mediator of the relationships of leadership behavior with job satisfaction and performance in a non-western country. Journal of Managerial Psychology, 15(1), 6-24. doi: 10.1108/02683940010305270

Zembylas, M., \& Papanastasiou, E. (2006). Sources of teacher job satisfaction and dissatisfaction in Cyprus. Compare: A Journal of Comparative and International Education, 36(2), 229-247. doi: 10.1080/03057920600741289 


\section{List of Figures and Tables}

Hereafter, all figures and tables, and their corresponding captions are enclosed.

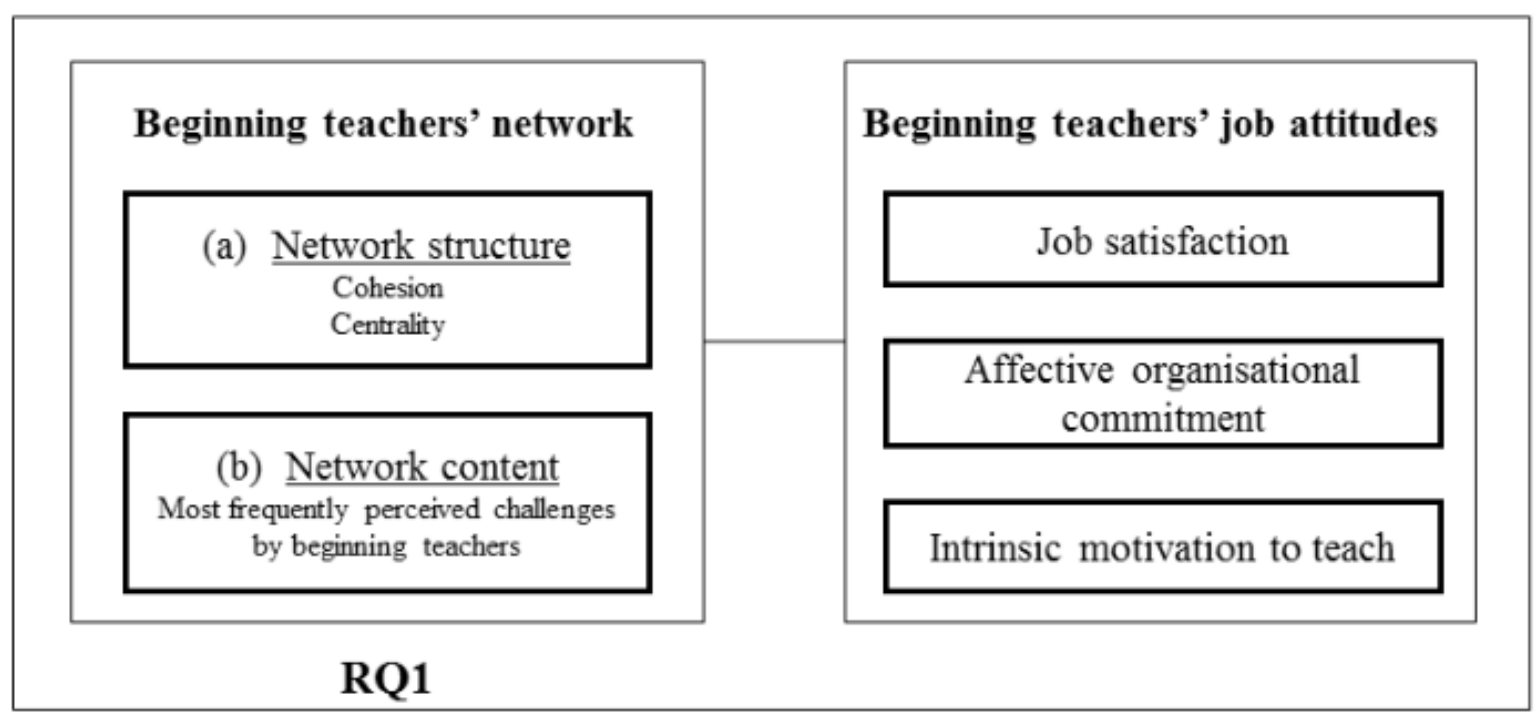

\section{RQ2}

Fig. 1. Visualisation of the study's research questions 


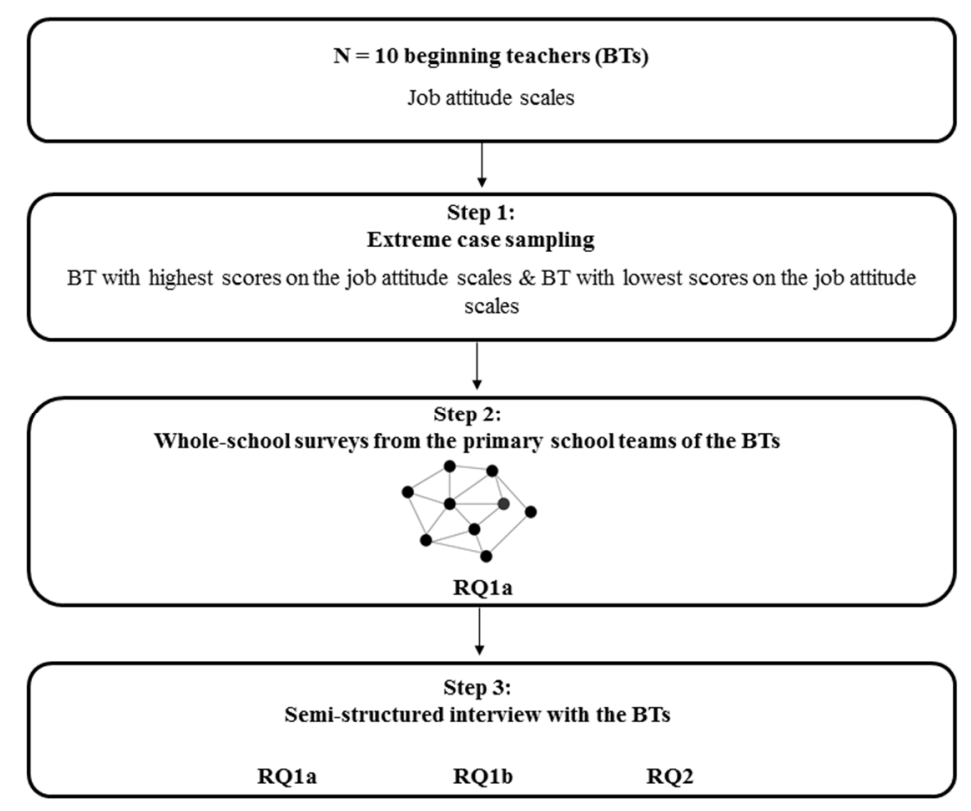

Figure 2. The overall study design 


\section{Table 1}

Overview of the validated scales to measure teachers' job attitudes

\begin{tabular}{|c|c|c|c|c|c|}
\hline Measure & Author & Example item & Range & Items & $\alpha$ \\
\hline Job satisfaction & $\begin{array}{l}\text { Caprara, } \\
\text { Barbaranelli, } \\
\text { Borgogni, \& Steca } \\
(2003)\end{array}$ & I feel good at work & $\begin{array}{l}\text { Strongly disagree }(0)- \\
\text { Strongly agree }(4)\end{array}$ & 4 & .78 \\
\hline $\begin{array}{l}\text { Affective } \\
\text { organisational } \\
\text { commitment }\end{array}$ & $\begin{array}{l}\text { McInerney, } \\
\text { Ganotice, King, } \\
\text { Marsh, \& Morin } \\
(2015)\end{array}$ & $\begin{array}{l}\text { I do not feel emotionally } \\
\text { attached to this school }\end{array}$ & $\begin{array}{l}\text { Strongly disagree }(0)- \\
\text { Strongly agree }(4)\end{array}$ & 3 & .71 \\
\hline $\begin{array}{l}\text { Intrinsic } \\
\text { motivation to } \\
\text { teach }\end{array}$ & $\begin{array}{l}\text { Soenens, Sierens, } \\
\text { Vansteenkiste, } \\
\text { Dochy, \& Goossens } \\
\text { (2012) }\end{array}$ & I find teaching enjoyable & $\begin{array}{l}\text { Strongly disagree }(0)- \\
\text { Strongly agree }(4)\end{array}$ & 4 & .88 \\
\hline
\end{tabular}




\section{Job Attitudes}

Job satisfaction ( $\mathrm{M}=3.10 ; \mathrm{SD}=.44)$; Affective organisational commitment $(\mathrm{M}=3.56$; $\mathrm{SD}=.61)$; Intrinsic motivation to teach $(\mathrm{M}=3.43 ; \mathrm{SD}=.51)$

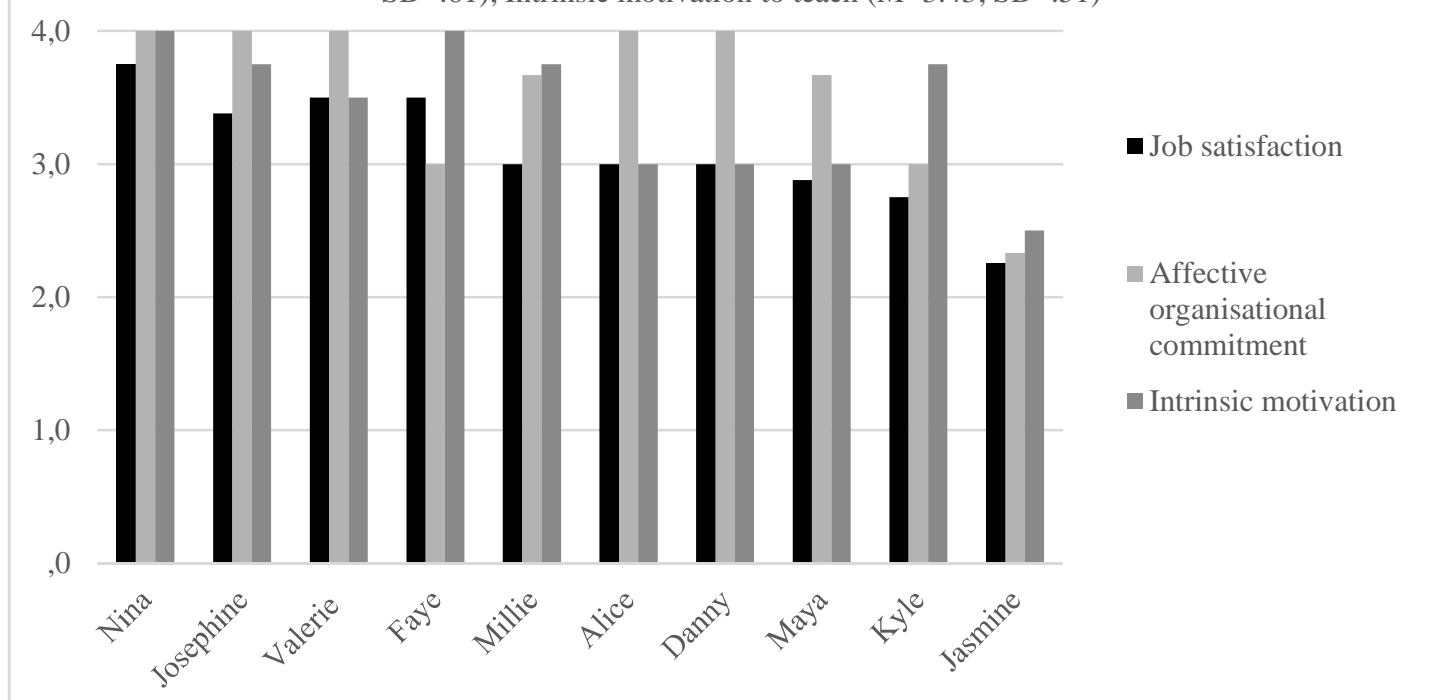

Figure 3. Ranking of the BTs based on their scores on the job attitudes scales. The ranking is based on the mean of the scores of job satisfaction, affective organisational commitment and intrinsic motivation to teach 

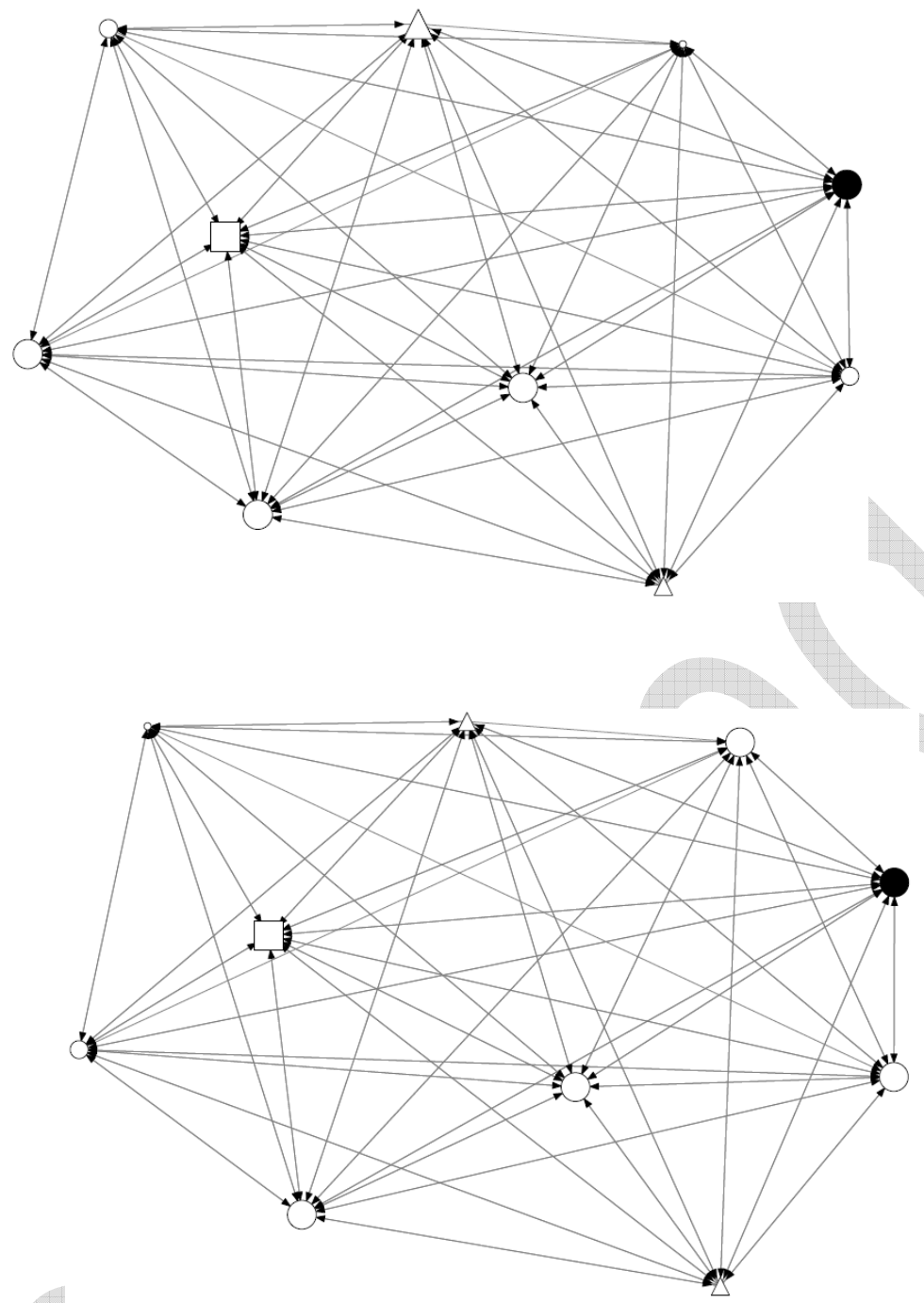

Figure 4. School network maps of Nina [West Bridge Elementary] in which nodes are sized according to outdegree (top picture) and in-degree (bottom picture). The bigger the node, the higher its out-degree (top picture); the bigger the node, the higher its in-degree (bottom picture). Every node represents a primary school team member. The colours of the nodes in the map depict the BT (black), and the other primary school team members (white). The shapes of the nodes in the map represent teachers (also special educational needs teachers and PE teachers) (circle), the principal (square) and others, e.g., special educational needs coordinator, ICT coordinator (triangle). The arrows specify the direction of the relations. 

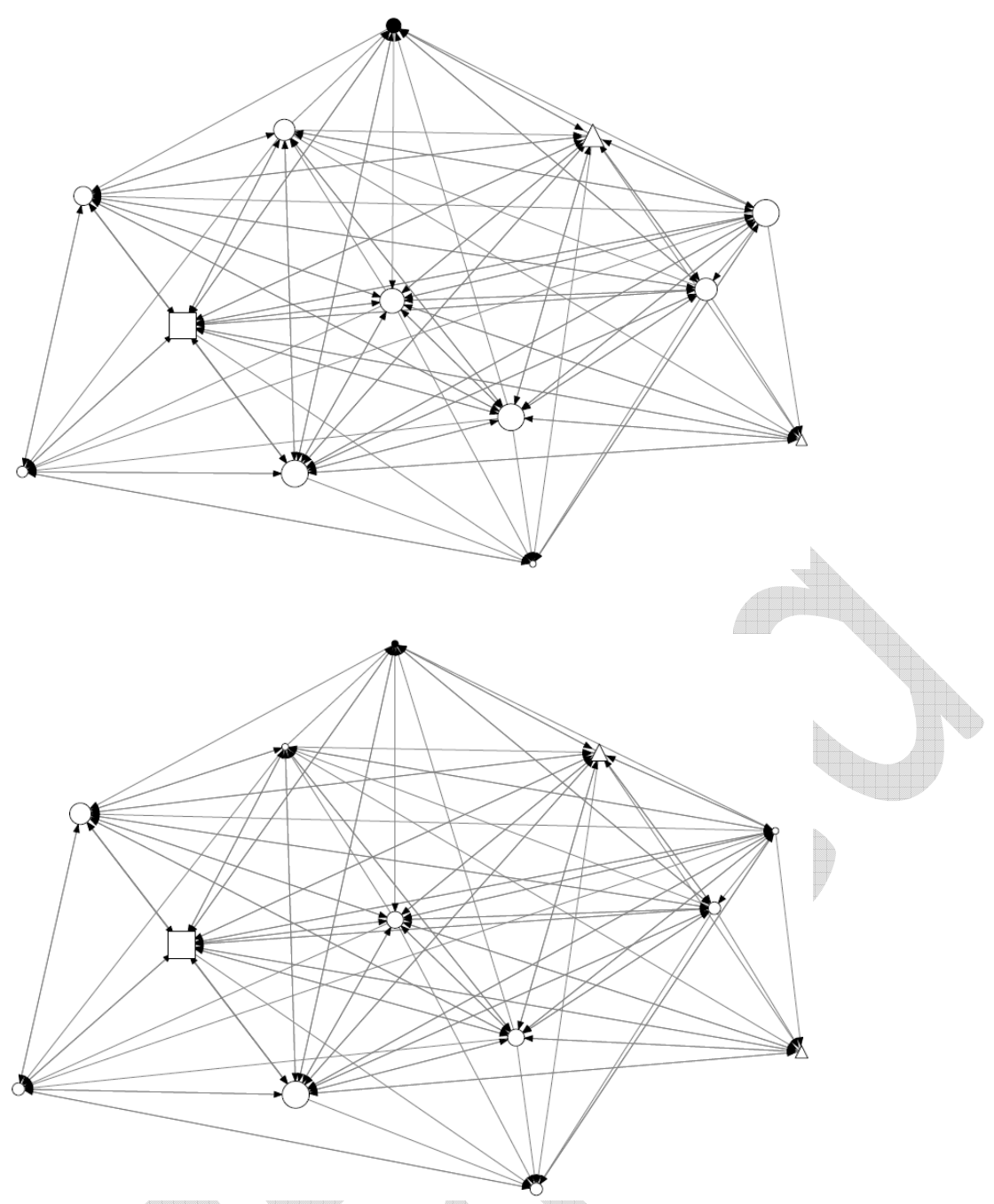

Figure 5. School network maps of Jasmine [Golden Oak] in which nodes are sized according to out-degree (top picture) and in-degree (bottom picture). The bigger the node, the higher its out-degree (top picture); the bigger the node, the higher its in-degree (bottom picture). Every node represents a primary school team member. The colours of the nodes in the map depict the BT (black), and the other primary school team members (white). The shapes of the nodes in the map represent teachers (also special educational needs teachers and PE teachers) (circle), the principal (square) and others, e.g., special educational needs coordinator, ICT coordinator (triangle). The arrows specify the direction of the relations. 


\section{Table 2}

Cohesion and centrality measures

\begin{tabular}{lcc}
\hline & Nina & Jasmine \\
\hline Density & .944 & .718 \\
Degree centralisation & .069 & .333 \\
Normalised out-degree & 1 & .500 \\
Normalised in-degree & 1 & .583 \\
Standard deviation normalised out-degree & .079 & .294 \\
Standard deviation normalised in-degree & .079 & .116 \\
\hline
\end{tabular}

Note. Density varies between 0 (no relationships among individuals in the network) and 1 (everyone is connected to everyone in the network); Degree centralisation ranges from 0 (all primary school team members have workrelated contact with only a single person in the network, while they themselves are not nominated as being a workrelated contact at all) to 1 (all primary school team members are nominated as a work-related contact as frequently); Normalised out-degree/in-degree vary between 0 (no outgoing ties/no incoming ties) and 1 (outgoing ties to/incoming ties from everyone in the network). 


\section{Table 3}

Content of the professional collegial support

\begin{tabular}{lcc}
\hline Challenge & \multicolumn{2}{c}{$\begin{array}{l}\text { Number of colleagues who offer support for this } \\
\text { particular challenge }\end{array}$} \\
\cline { 2 - 3 } & Nina & Jasmine \\
\hline Classroom management and discipline & 6 & 0 \\
Motivating pupils & 0 & 0 \\
Dealing with individual differences in the classroom & 2 & 3 \\
Instructional and assessment strategies & 2 & 1 \\
Communication with parents & 2 & 1 \\
Organisation of class work & 3 & 1 \\
Teaching materials & 3 & 1 \\
Dealing with problems of individual pupils & 6 & 1 \\
\hline
\end{tabular}

Note. The frequencies reported in this table reflect the number of colleagues who offer support to the BT for the specific challenge, not the number of times the BT mentions support concerning the specific challenge (e.g., if the beginning teacher provides several examples of 'instructional and assessment strategies' within the same support tie, this is counted as 'one') 